\title{
BIOMECHANICS OF NON-CARIOUS CERVICAL LESIONS IN FINITE ELEMENT MODELS: AN INTEGRATIVE REVIEW
}

\section{BIOMECÂNICA DE LESÕES CERVICAIS NÃO-CARIOSAS EM MODELOS DE ELEMENTOS FINITOS: UMA REVISÃO INTEGRATIVA}

\section{Ricardo Barbosa-Lima}

Graduate Student of Dentistry - Federal University of Sergipe - UFS, Lagarto/SE.

\section{Sabrina Nascimento Ribeiro}

Graduate Student of Dentistry - Federal University of Sergipe - UFS, Lagarto/SE.

\section{Juliely Nascimento Furtado de Moura}

Graduate Student of Dentistry - Federal University of Sergipe - UFS, Lagarto/SE.

\section{Amanda Lopes}

Graduate Student of Dentistry - Federal University of Sergipe - UFS, Lagarto/SE.

\section{Isaías Queiroz Soares Silva}

Graduate Student of Dentistry - Federal University of Sergipe - UFS, Lagarto/SE.

\section{Daniel Maranha da Rocha}

Undergraduate Professor of Dentistry - Federal University of Sergipe - UFS, Lagarto/SE.

\section{Katharina Morant Holanda de Oliveira-Vanderlei}

Undergraduate Professor of Dentistry - Federal University of Sergipe - UFS, Lagarto/SE.

Institution: Federal University of Sergipe - UFS, Lagarto/SE.

Category: Review Article 
Correspondence: Mr. Ricardo Barbosa-Lima. Address: Avenida Gov. Marcelo Déda, São José, Lagarto, Sergipe, Brazil. ZIP code: 49.400-000. Phone: (79) 3632-2082. E-mail: ricardoblima17@gmail.com. 


\begin{abstract}
Non-carious cervical lesions affect permanent teeth and cause the loss of healthy dental structure through a non-bacterial process. The occurrence of these lesions is multifactorial, although components of the occlusion are frequently associated. The objective of this article is to present a biomechanics of non-carious cervical lesions in finite element models. It is an integrative review of in silico studies carried out in PubMed, Scopus and Web of Science databases, using a PICo search strategy with descriptors. Studies in three dimensions carried out using finite element softwares that evaluated the biomechanical behavior of non-carious cervical lesions, without language restriction, published between 2000 and 2019 were included. Nine studies were eligible, analyzed and synthesized. The evidence indicates that when oblique occlusal forces are applied, the cervical zone of the dental elements receives greater stress, especially in the subsurface enamel. Furthermore, enamel can be more susceptible to stress than dentin, while V-shaped cervical lesions tend to receive more stress than U-shaped lesions, as well as the depth of these lesions potentially increases stress. Bone support and root morphology can modify the distribution of occlusal forces in dental elements. Thus, the biomechanical behavior of non-carious cervical lesions in finite element models is directly associated with oblique occlusal forces capable of generating tension in the cervical of dental elements.
\end{abstract}

Keywords: Tooth Wear; Bite Force; Dental Stress Analysis; Review Literature as Topic. 


\section{RESUMO}

As lesões cervicais não-cariosas acometem os dentes permanentes e provocam a perda da estrutura dentária saudável por meio de um processo não-bacteriano. A ocorrência destas lesões é multifatorial, embora componentes da oclusão estejam frequentemente associados. O objetivo deste artigo é apresentar a biomecânica de lesões cervicais não-cariosas em modelos de elementos finitos. Trata-se de uma revisão integrativa de estudos in silico desenvolvida nas bases de dados PubMed, Scopus e Web of Science utilizando uma estratégia de busca com descritores. Foram selecionados estudos em três dimensões desenvolvidos em softwares de elementos finitos que avaliaram o comportamento biomecânico de lesões cervicais não-cariosas, sem restrição de idioma, publicados entre 2000 e 2019. O rastreamento e a seleção dos estudos foram realizados por dois avaliadores independentes. Nove estudos foram elegíveis, analisados e sintetizados. As evidências indicam que, quando forças oclusais oblíquas são aplicadas, a região cervical dos elementos dentais recebe maior estresse, especialmente no esmalte subsuperficial. Além disso, o esmalte pode ser mais suscetível ao estresse que a dentina, enquanto as lesões cervicais em forma de "V" tendem a receber mais estresse do que lesões em forma de "U", bem como a profundidade dessas lesões aumentam potencialmente o estresse. O suporte ósseo e a morfologia radicular podem modificar a distribuição das forças oclusais nos elementos dentais. Sendo assim, o comportamento biomecânico de lesões cervicais não-cariosas em modelos de elementos finitos está diretamente associado à cargas oclusais oblíquas que são capazes de gerar tensões na cervical dos elementos dentais.

Palavras-chave: Desgaste dos Dentes; Força de Mordida; Análise do Estresse Dentário; Literatura de Revisão como Assunto. 


\section{INTRODUCTION}

Non-carious cervical lesions, especially the abfraction type lesions, are loss of dental structure close to the cemento-enamel junction, without bacterial involvement, presenting a wedge shape. The etiology of these structural losses is often multifactorial and the evidence supports that inappropriate occlusal forces are related to the emergence of the abfraction (SRIREKHA; BASHETTY, 2013; CHANG et al., 2019; HARALUR et al., 2019).

The occlusal forces and their relationship with the abfraction lesions have been investigated in studies with finite element models. The analysis of this relationship by finite elements can be a viable method in the evaluation of complex biomechanics of the oral cavity, especially when the conditions necessary to evaluate them can not be easily reproduced in vivo (SRIREKHA; BASHETTY, 2013; CHANG et al., 2019; HARALUR et al.,

With the advancement of computational software applied to dental sciences, studies with finite elements in three dimensions have become an analytical method for biomechanical events of teeth and other oral tissues, being part of studies called in silico. It is possible to reproduce dental structures, determine their properties and study their behavior in different mechanics, such as the application of forces and their distribution (CHANG et al., 2019; HARALUR et al., 2019).

Understanding the processes by which dental elements lose mineral structure in the cervical zone is complex and has not yet been fully elucidated. However, according to the theory of tooth flexion, the occlusal forces are dissipated from the axial axis towards the cervical zones and the chemical bonds of the enamel hydroxyapatites can be damaged, initiating the loss of structure in this region (SADAF; AHMAD, 2014; MARINESCU et al., 2017).

Non-carious cervical lesions are common in the dental clinical practice, can compromise aesthetics, pulp vitality, cause dentinal hypersensitivity, favor biofilm retention 
and decrease tooth longevity (NASCIMENTO et al., 2016). The objective of this article is to present a biomechanics of non-carious cervical lesions in finite element models.

\section{METHODS}

An integrative literature review was carried out in the Medical Literature Analysis and Retrieval System Online (MEDLINE/PubMed), Scopus e Web of Science databases. The gray literature were consulted in OpenGrey and OpenThesis databases. In addition, manual searches in the references of eligible articles were performed, aiming to track the largest number of studies. The searches started in 2019, between May 10 and June 7.

The search strategy used in all databases comprises the PICo technique to assess problem (P: non-carious cervical lesions), interest (I: biomechanics) and context (Co: finite element models). The terms used were combined in the referred bases by means of Boolean operators: (“Abfraction” OR "Non Carious Cervical Lesions” OR "Cervical Tooth Region”) AND ("Bite Forces" OR "Occlusal Forces" OR "Biomechanical”) AND ("Finite Element Method" OR "Finite Element Analysis" OR "Finite Element Model” OR "Finite Element Modelling"). The same search strategy was applied in all databases accessed in this review.

The guiding question for the development of this bibliographic research was: what is the available evidence on the biomechanics of non-carious cervical lesions in studies with finite element models? As inclusion criteria, were eligible computer simulation studies using a finite element model (in silico) in three dimensions (3D), which evaluated several biomechanical aspects of the formation of non-carious cervical lesions, such as the amount of load, load distribution, lesion progression in the cervical zone and influence of other oral structures. There was no language restriction and studies published between the years 2000 and 2019 were considered. Studies without adequate methodological description, with incomplete analyzes, which did not use finite elements or use other software were excluded.

The selection of eligible articles according to the criteria presented was performed using an exploratory and qualitative reading of the titles, abstracts and full-text by two independent reviewers. The information of both was crossed and the disagreements were 
defined by a third evaluator. Data extraction was guided by a pilot form to record the data of interest.

\section{RESULTS AND DISCUSSION}

After applying the search strategy, 130 articles were tracked in the databases. In manual searches, six articles were added and no article was reached when consulting gray literature. Of the 136, 64 represented duplications and 58 were irrelevant to the proposed objective, resulting in 14 articles for full-text reading. Of this total, three were two-dimensional studies, one study did not evaluate non-carious cervical lesions and one study did not use finite elements. Therefore, five articles were excluded and nine met the inclusion criteria, being analyzed and synthesized.

Considering the finite element method in the nine studies, one evaluated maxillary central incisor (VANDANA et al., 2016), one evaluated maxillary canine (ROMEED; MALIK; DUNNE, 2012), three evaluated mandibular premolars (PALAMARA et al., 2000) and four evaluated maxillary premolars (LEE et al., 2002; SOARES et al., 2014; GUIMARÃES et al., 2014; MUNARI et al., 2015). In these studies, the amount of applied occlusal load varied between 45 and $290 \mathrm{~N}$, in order to understand the behavior of dental structures under these forces. In summary, these studies suggest that the occurrence of stresses in the cervical zone of dental elements is associated with the application of forces in oblique directions, outside the axial axis, resulting in stress to the mineral structure.

Within the cervical zone of teeth in finite element models, the concentration of stress due to the application of excessive occlusal loads occurs in the subsurface layer of the enamel. In this perspective, the amount of stress can be up to five times greater than that of the superficial enamel, suggesting that the onset of non-carious cervical lesions occurs initially in the subsurface (JAKUPOVIC et al., 2014; JAKUPOVIC et al., 2016).

V-shaped lesions in the cervical zone of dental elements in finite models have a higher concentration of stresses when subjected to functional and non-functional oblique loads. In 
this lesion shape, when occlusal loads are applied, the greatest concentration of stresses is located at the zenith (GUIMARÃES et al., 2014; JAKUPOVIC et al., 2016).

On the other hand, U-shaped lesions have lower stress concentrations when subjected to the same conditions and compared with V-shaped. The concentration of stresses is located in a wider area in U-shaped lesions, especially at the edges. In addition, the depth of the lesion is directly associated with increased stress throughout the zenith (GUIMARÃES et al., 2014; JAKUPOVIC et al., 2016). Occlusal forces can play an important role in the progression of these injuries (SAWLANI et al., 2016).

In addition, the presence of periodontal support, especially bone support, is associated with the concentration of stress by occlusal loads in the cervical zone of dental elements in finite models. As bone support is lost, stress transmission and concentration tend to migrate from the cervical to a more apical zone. For this reason, it is suggested that abfraction-type lesions are less likely to occur in periodontally compromised teeth, since the cervical zone will not receive potential stress (VANDANA et al., 2016; REDDY; VANDANA, 2018).

Considering the supporting bone tissue, when non-functional oblique loads are applied, the amount of stress directed to the bone can be ten times greater compared to axial loads, suggesting a justification for the bone resorption observed in occlusal trauma (JAKUPOVIC et al., 2014; REINHARDT; KILLEEN, 2015; JAKUPOVIC et al., 2016). In addition, the application of oblique forces in teeth with two roots and associated with a deeper fraction injury $(2.5 \mathrm{~mm})$ showed higher concentrations of stress in the cervical area when compared to uniradicular teeth or with less deep fraction injury $(1.5 \mathrm{~mm}$ ) (SOARES et al., 2014; JAKUPOVIC et al., 2016).

Considering the axial loads in enamel and dentin separately, when an oblique force is applied, the stress located in the enamel can be up to three times higher than dentin, suggesting that the first may be more susceptible to stress caused by occlusal forces in finite element tests. However, it is important to note that there is an increase in stress in both structures (ROMEED; MALIK; DUNNE, 2012). 
$3 \mathrm{D}$ analysis is desirable when using finite elements. 3D modeling allows more accurate results and more detailed optical evaluation of the anatomy of dental elements in software. In finite elements, loads between $200 \mathrm{~N}$ and $400 \mathrm{~N}$ can represent inappropriate forces on dental tissues, as well as loads close to $90 \mathrm{~N}$ are compatible with physiological forces. However, an oblique force of $105 \mathrm{~N}$ can induce tension in the cervical zone (SRIREKHA; BASHETTY, 2013; GUIMARÃES et al., 2014; CHANG et al., 2019).

In the cervical zone of the dental elements, there is a transition in the orientation of the hydroxyapatite prisms that comprise them. When approaching the cementitious junction, there is a tendency to flatten and reduce the thickness of the enamel, in addition to having a lower mineral density. Such histological characteristics suggest that the cervical zone may be more vulnerable to irritating agents and stressors, correlating with the appearance of cervical lesions (DUANGTHIP et al., 2017; KOLAK et al., 2018).

Furthermore, evidence suggests that premolars are the dental elements most clinically affected by non-carious lesions in the cervical zone. Among the possible reasons for this phenomenon, the incidence of premature occlusal contacts frequently observed in this group of teeth, in addition to the inclination of the vestibular cusps and the group laterality function, are acceptable explanations (IGARASHI; YOSHIDA; KANAZAWA, 2017; MACHADO et al., 2017; YOSHIZAK et al., 2017; KOLAK et al., 2018).

Although biomechanical analyzes are an interesting tool in the study and understanding of occlusal stress phenomena, the use of finite elements in the reviewed studies was based on dental elements of standard occlusal morphology. However, it is common to observe pathological wear, fractures, flattening and other structural changes that can interfere with the dispersion of forces in natural teeth (NASCIMENTO et al., 2016; MARINESCU et al., 2017). In the studies synthesized by this integrative review, such changes were not tested in silico, being an important limitation. In addition, we have not found validated tools for analyzing the risk of bias in studies of this nature.

Another important point to be considered is that, although the scientific literature reports an association between the appearance of cervical lesions and the performance of 
occlusal forces outside the axial axis of dental elements, other factors are considered in this process, such as oral hygiene habits, abrasive toothpastes and consumption of acidic foods. In addition, the wine and alcoholic beverages intake was also associated with the prevalence of non-carious cervical lesions (MARINESCU et al., 2017; YOSHIZAK et al., 2017; HARALUR et al., 2019).

\section{CONCLUSION}

The biomechanical behavior of non-carious cervical lesions was directly associated with oblique non-functional occlusal loads directed to dental elements in finite models. When occlusal forces outside the axial axis of the dental elements were applied, the concentration of stress was greater in the cervical zone. The shape of the lesion, bone support and root morphology are factors that influence the distribution of this stress. The understanding of this behavior in silico can help new studies in vivo to evaluate the appearance of non-carious cervical lesions. 


\section{REFERENCES}

1. Srirekha A, Bashetty K. A comparative analysis of restorative materials used in abfraction lesions in tooth with and without occlusal restoration: three-dimensional finite element analysis. J Conserv Dent., 2013;16(2):157-61. DOI: https://dx.doi.org/10.4103\%2F0972$\underline{0707.108200 .}$.

2. Chang YH, Chan MY, Hsu JT, Hsiao HY, Su KC. Biomechanical analysis of the forces exerted during different occlusion conditions following bilateral sagittal split osteotomy treatment for mandibular deficiency. Appl Bionics Biomech., 2019;2019:4989013. DOI: https://doi.org/10.1155/2019/4989013.

3. Haralur SB, Alqahtani AS, AlMazni MS, Alqahtani MK. Association of non-carious cervical lesions with oral hygiene habits and dynamic occlusal parameters. Diagnostics (Basel)., 2019;9(2):43. DOI: https://doi.org/10.3390/diagnostics9020043.

4. Sadaf D, Ahmad Z. Role of brushing and occlusal forces in non-carious cervical lesions (NCCL). Int J Biomed Sci., 2014;10(4):265-8.

5. Marinescu IR, Popescu SM, Răghici EC, Scrieciu M, Mercuț V, Turcu AA, et al. Etiological aspects of noncarious dental lesions. Curr Health Sci J., 2017;43(1):54-61. DOI: https://dx.doi.org/10.12865\%2FCHSJ.43.01.08.

6. Nascimento MM, Dilbone DA, Pereira PN, Duarte WR, Geraldeli S, Delgado AJ. Abfraction lesions: etiology, diagnosis, and treatment options. Clin Cosmet Investig Dent., 2016;8:79-87. DOI: https://doi.org/10.2147/ccide.s63465.

7. Jakupović S, Anić I, Ajanović M, Korać S, Konjhodžić A, Džanković A, Vuković A. Biomechanics of cervical tooth region and noncarious cervical lesions of different morphology; three-dimensional finite element analysis. Eur J Dent., 2016;10(3):413-418. DOI: https://doi.org/10.4103/1305-7456.184166. 
8. Jakupovic S, Cerjakovic E, Topcic A, Ajanovic M, Prcic AK, Vukovic A. Analysis of the abfraction lesions formation mechanism by the finite element method. Acta Inform Med., 2014;22(4):241-5. DOI: https://doi.org/10.5455/aim.2014.22.241-245.

9. Reinhardt RA, Killeen AC. Do mobility and occlusal trauma impact periodontal longevity? Dent Clin North Am., 2015;59(4):873-83. DOI: https://doi.org/10.1016/j.cden.2015.06.003.

10. Guimarães JC, Guimarães Soella G, Brandão Durand L, Horn F, Narciso Baratieri L, Monteiro S Jr, et al. Stress amplifications in dental non-carious cervical lesions. J Biomech., 2014 Jan;47(2):410-6. DOI: https://doi.org/10.1016/j.jbiomech.2013.11.012.

11. Sawlani K, Lawson NC, Burgess JO, Lemons JE, Kinderknecht KE, Givan DA, et al. Factors influencing the progression of noncarious cervical lesions: A 5-year prospective clinical evaluation. J Prosthet Dent., 2016;115(5):571-7. DOI: https://doi.org/10.1016/j.prosdent.2015.10.021.

12. Vandana KL, Deepti M, Shaimaa M, Naveen K, Rajendra D. A finite element study to determine the occurrence of abfraction and displacement due to various occlusal forces and with different alveolar bone height. J Indian Soc Periodontol., 2016;20(1):12-6. DOI: https://dx.doi.org/10.4103\%2F0972-124X.168484.

13. Reddy RT, Vandana KL. Effect of hyperfunctional occlusal loads on periodontium: A three-dimensional finite element analysis. J Indian Soc Periodontol., 2018;22(5):395-400. DOI: https://doi.org/10.4103/jisp.jisp_29_18.

14. Soares PV, Souza LV, Veríssimo C, Zeola LF, Pereira AG, Santos-Filho PC, et al. Effect of root morphology on biomechanical behaviour of premolars associated with abfraction lesions and different loading types. J Oral Rehabil., 2014;41(2):108-14. DOI: https://doi.org/10.1111/joor.12113. 
15. Romeed SA, Malik R, Dunne SM. Stress analysis of occlusal forces in canine teeth and their role in the development of non-carious cervical lesions: abfraction. Int $\mathbf{J}$ Dent., 2012;2012:234845. DOI: https://doi.org/10.1155/2012/234845.

16. Munari LS, Cornacchia TP, Moreira AN, Gonçalves JB, De Las Casas EB, Magalhães CS. Stress distribution in a premolar 3D model with anisotropic and isotropic enamel. Med Biol Eng Comput., 2015;53(8):751-8. DOI: https://doi.org/10.1007/s11517-015-1289-4.

17. Lee HE, Lin CL, Wang $\mathrm{CH}$, Cheng $\mathrm{CH}$, Chang $\mathrm{CH}$. Stresses at the cervical lesion of maxillary premolar--a finite element investigation. J Dent., 2002;30(7-8):283-90. DOI: https://doi.org/10.1016/s0300-5712(02)00020-9.

18. Palamara D, Palamara JE, Tyas MJ, Messer HH. Strain patterns in cervical enamel of teeth subjected to occlusal loading. Dent Mater., 2000;16(6):412-9. DOI: https://doi.org/10.1016/s0109-5641(00)00036-1.

19. Kolak V, Pešić D, Melih I, Lalović M, Nikitović A, Jakovljević A. Epidemiological investigation of non-carious cervical lesions and possible etiological factors. J Clin Exp Dent., 2018;10(7):e648-e656. $\quad$ DOI: $\quad \underline{\text { https://doi.org/10.4317/jced.54860. }}$

20. Duangthip D, Man A, Poon PH, Lo ECM, Chu CH. Occlusal stress is involved in the formation of non-carious cervical lesions. A systematic review of abfraction. Am J Dent., 2017;30(4):212-220.

21. Yoshizaki KT, Francisconi-Dos-Rios LF, Sobral MA, Aranha AC, Mendes FM, Scaramucci T. Clinical features and factors associated with non-carious cervical lesions and dentin hypersensitivity. J Oral Rehabil., 2017;44(2):112-118. DOI: https://doi.org/10.1111/joor.12469.

22. Machado AC, Soares CJ, Reis BR, Bicalho AA, Raposo L, Soares PV. Stress-strain analysis of premolars with non-carious cervical lesions: influence of restorative material, loading direction and mechanical fatigue. Oper Dent., 2017;42(3):253-265. DOI: 
https://doi.org/10.2341/14-195-1.

23. Igarashi Y, Yoshida S, Kanazawa E. The prevalence and morphological types of noncarious cervical lesions (NCCL) in a contemporary sample of people. Odontology. 2017;105(4):443-452. DOI: https://doi.org/10.1007/s10266-017-0300-y. 